\title{
Håp og livsmot i sykdomsfortellinger etter hjerneslag
}

\author{
Gabriele Kitzmüller \\ Gabriele Kitzmüller, klinisk spesialist, spesialsykepleier $i$ aldring og eldre- \\ omsorg, førsteamanuensis PhD, UiT Norges Arktiske Universitet, Det Helse- \\ vitenskapelige Fakultet, Institutt for Helse og Omsorg, Narvik \\ gabriele.e.kitzmuller@uit.no
}

\begin{abstract}
Hope and life courage in illness narratives after stroke

This essay illuminates the meaning of hope and life courage in the narratives of Tomas and Maria, a couple who had experienced the life changing consequences of Maria's stroke. Hope is supported by the couple's strong and loving relationship and by empathy and caring in their relationships with professional caregivers. In this way, the relational component of hope is revealed as the most important prerequisite for maintaining hope. The analysis demonstrates that life courage and hope are strongly needed for trust in the future and rehabilitation efforts. However, careless and unprofessional attitudes and practices of clinicians may lead to loss of control, poorer self-image and hopelessness. To support the hope of patients and relatives, clinicians must show caring attitudes and use both medical and humanistic knowledge. They should not devalue the phenomenon of hope as unrealistic.
\end{abstract}

\section{Keyword/Nøkkelord}

hope; life courage; health care professionals, caring relationships, information; Gabriel Marcel

håp; livsmot; helsepersonell; omsorgsfulle relasjoner; informasjon; Gabriel Marcel

\section{Referee*}


«But nobody can live without hope, even if it were only for the smallest things which give some satisfaction even under the worst conditions, even in poverty, sickness and social failure. Without hope the tension of our life towards the future would vanish, and with it, life itself.» (Tillich, 1965:371).

I mitt virke som sykepleier i ulike praksisfelt har jeg hatt anledning til å lytte til mange sykdomsfortellinger. Pasientenes fortellinger har hjulpet meg å bli kjent med personen som lever med sykdommen, noe som gjorde det lettere for meg å individualisere omsorgen. Fortellingene har gitt meg en bedre forståelse for hvordan ulike personer opplever sin sykdom, hvilken mening de tillegger den, og hvordan de ser for seg å leve videre med kronisk sykdom og funksjonshemming.

I senere år har jeg som forsker gransket sykdomserfaringer til personer som rammes av hjerneslag og deres pårørende (Kitzmüller, 2012). Målet har vært å avdekke den dypere mening i slike beretninger for å komme frem til ny kunnskap som helsepersonell kan bruke i sin arbeidshverdag. $\AA$ lytte til sykdomsfortellinger som sykepleier eller forsker betyr å lytte på forskjellig vis, men formålet er det samme. Det vi lærer av fortellingene skal brukes til beste for pasienter og pårørende.

Som forsker ser jeg at deltakerne ofte innleder sine fortellinger med å beskrive sykdomshendelsen i detalj, selv om den ligger langt tilbake i tid (Kitzmüller, Häggström, Asplund \& Gilje, 2012). Fortellingene gir et tydelig bilde av hvordan sykdommen griper inn i livet. En ung hjerneslagrammet mor beskriver det slik: «I det ene фyeblikket var jeg på nattevakt på sykehuset og passet på de syke, og i neste фyeblikk lå jeg der selv, slagrammet og hjelpelфs».

Å bli rammet av et moderat eller alvorlig hjerneslag betyr at livet blir snudd opp ned fordi mange av kroppens fysiske og kognitive funksjoner settes ut av spill (Kitzmüller, Häggström \& Asplund, 2013; Salter, Hellings, Foley, \& Teasell, 2008). Mange mislykkes med å gjenoppta arbeidslivet (Brannigan et al., 2017), familiære relasjoner og roller endres (Kitzmüller \& Asplund, 2018) og betydningsfulle aktiviteter og sosiale nettverk går tapt (Teasdale \& Engberg, 2005). Mange slagrammede får et dårligere selvbilde (Kitzmüller, Häggström \& Asplund, 2013) og må leve med psykiske reaksjoner (Schöttke, Giabbiconi, \& Schöttke, 2015), kroniske smerter (Edgley \& Gershkoff, 2010) og tretthet (Duncan et al., 2012). De store endringene som et alvorlig hjerneslag kan medføre, forklarer hvorfor hendelsesforløpet tar så stor plass i sykdomsfortellingen. Det er nettopp der livet endret seg! Ifølge Frank (2013:60) oppleves ikke sykdomserfaringer som fortid fordi minnene stadig vekk hjems $\varnothing$ ker fortelleren.

Jeg har merket meg hvor viktig det er for deltakerne å finne en forklaring på hvorfor de ble rammet. De kan gruble over hvorfor de ikke endret sin livsstil 
tidsnok eller tok konsekvensene av en arvelig disposisjon (Kitzmüller, Häggström, Asplund \& Gilje, 2012). Jeg ser dette som et uttrykk for vår menneskelige streben med å skape forståelse og mening i en ellers tilsynelatende meningsløs sykdomsopplevelse. Dette meningsskapende arbeidet ser ut til å være viktig for å forstå sykdommen og dens konsekvenser og kan berede grunnen for å kunne opprettholde håp og livsmot (Kitzmüller, Häggström, Asplund \& Gilje, 2012). Livsmot defineres i denne sammenhengen som: «Vilje og lyst til å leve, ofte på tross av motgang eller svekkelse» ${ }^{1}$. Men deltakernes fortellinger handler om mye mer enn det akutte forløpet. De beretter om hvordan de takler utfordringene og hvordan de prøver å leve med endringene så godt det lar seg gjøre. De tilpasser seg, fortsetter å trene i årevis, setter seg stadig nye mål, kjemper imot eller faller til ro. De aller fleste fortsetter med å leve i håp om bedring, og mange opplever kontinuerlig fremgang gjennom mange år (Kitzmüller, Häggström, Asplund \& Gilje, 2012).

Det finnes mange ulike forståelser og definisjoner av begrepet håp. Den franske filosofen Gabriel Marcel (1978) har befattet seg inngående med håpets betydning. Marcel fastslår at håpet springer ut av situasjoner som kan sammenliknes med å være fanget og som medfører prøvelser, tap og fremmedgjøring. I slike situasjoner oppdager vi rekkevidden av det som er gått tapt og lengter etter å få det tilbake (30-31). Marcel ser håpet som en prosess hvor mennesket tålmodig setter sine krefter i spill, i visshet om at livet byr på uunngåelig motgang. Marcel hevder at håpet kan overleve en nærmest fullstendig tilintetgjøring av organismen, på samme tid som den byr på en kraft som opprettholder livet (37). Denne påstand er i overenstemmelse med opplevelsene til den jødiske psykiateren og filosofen Viktor Frankl (1993) som var fange i konsentrasjonsleir under 2.verdenskrig. Frankl hadde i lengre tid arbeidet med å utvikle en egen teori om menneskets søken etter mening. Hans teori ble nå bekreftet av egne observasjoner og opplevelser i leiren. Overlevelsen var betinget av at fangene klarte å bevare håpet om å overleve sult, kulde, nedverdigelse og sykdom ved å finne mening i en tilsynelatende meningsløs tilværelse. Å kunne hjelpe medfanger eller rette tankene mot fremtiden og et håp om gjensyn med familien eller fullbyrdelsen av et livsverk, kunne gi nødvendig livskraft til å holde ut lidelsene. Ansikt til ansikt med avmakt og fornedrelse fant Frankl (1993) mening i vissheten om at det likevel stod i hans makt å bære lidelsen med verdighet.

Farran, Herth og Popovich (1995) som har videreutviklet Marcels (1978) tenkning, definerer håp som en essensiell menneskelig erfaring som preger følelsesliv, tankeliv og handlingsmønster. Å leve i håpet er en måte å forholde seg på, både til seg selv og til ens omverden (Farran et al., 1999:6). Håpets

\footnotetext{
${ }^{1}$ Den Danske ordbog, Moderne Dansk Sprog https://ordnet.dk/ddo/ordbog?query=livsmod (min oversettelse)
} 
forventninger er tilpasningsdyktige, for selv om det ønskede resultat uteblir kan håpet holdes levende (6). På bakgrunn av sin forskning fant Farran og kolleger at håpet har fire attributter som de kaller håpets smerte, håpets sjel, håpets forstand $\mathrm{og}$ håpets hjerte. Disse fire egenskapene karakteriserer håpets erfaringsmessige, spirituelle, rasjonelle og relasjonelle dimensjon. Som regel er håpet rotfestet $\mathrm{i}$ en uunngåelig $\mathrm{og}$ smertefull erfaring. Håpets spirituelle dimensjon kan forklares med troen på at den vanskelige nå-situasjon kan bedres i fremtiden, og håpets rasjonelle dimensjon har sitt rotfeste i den reelle her-ognå-situasjon. Personen det gjelder, fors $\emptyset$ ker å aktivisere alle sine ressurser for å ta kontroll over situasjonen og prøver å handle rasjonelt ut fra tidligere mestringserfaringer. Håpets relasjonelle dimensjon blir virksom gjennom betydningsfulle medmennesker som kan blåse liv i et skjørt håp.

I det følgende vil jeg gjenfortelle sykdomsberetningen til ekteparet Maria $^{2}$ og Tomas. Fortellingen er på ingen måte unik, men den er et eksempel på hvilken betydning håp og livsmot har både for den som får kjenne sykdommen på kroppen og for den som står nærmest.

\section{Håp og livsmot i sykdommens kaos}

Ekteparet er i slutten av 40 årene, og de er yrkesaktive foreldre til to ungdommer som nylig har flyttet hjemmefra, når Maria rammes av et alvorlig hjerneslag. Hun blir liggende i koma i flere uker og er avhengig av respiratorbehandling. De første dagene etter hjerneblødningen får Tomas vite at det ikke er store sjanser for at Maria vil overleve. Tomas tilbringer dagene på intensivavdelingen sammen med henne, og han opplever svingningene i hennes tilstand på nært hold. Etter at de første kritiske dagene er passert, forteller legene at Marias sjanser $\varnothing$ ker for hver dag som går. For Tomas blir bedringen et halmstrå å klamre seg til, noe som hjelper ham å takle engstelser og bekymringer i denne kaotiske tiden. Han opplever at legene og sykepleierne opptrer støttende og omsorgsfull. De er profesjonelle, samtidig som de viser ekte medfølelse. Det er smertefullt og følelsesladet for Tomas å se tilbake på denne vanskelige tiden da Maria svevde i grenseland mellom liv og død. Tomas forteller fra tiden på intensivavdelingen:

«Jeg ble tatt vare på som aldri før i mitt liv ... det var som om jeg var del av en familie. Jeg traff noen sykepleiere som jeg aldri vil glemme. Jeg husker veldig godt hvordan sykepleierne tok vare på kona mi, spesielt to av dem. De behandlet henne veldig bra. Jeg folte meg fullstendig trygg. Jeg kunne legge meg og sove uten å bekymre meg for Maria. Jeg husker en episode, det var en sykepleier, hun hadde kontroll på alt. Hun nektet å gå hjem selv om hennes skift var over. Hun ville følge med hvordan det gikk etter at Maria ble ekstubert ${ }^{3}$... Måten

\footnotetext{
${ }^{2}$ Alle informanter har fått fiktive navn

$3 \AA$ À ekstubere betyr at man fjerner røret som er satt inn i luftrøret og som er koblet til en respirator (pustemaskin).
} 
sykepleierne kommuniserte med Maria, selv om hun var bevisstløs, var utrolig bra ... Jeg kunne stole på de menneskene 100 prosent.»

Den kritiske situasjon som Maria og Tomas befinner seg i etter at Maria får en livstruende hjerneblødning er det som Farran og kolleger (1995) kaller håpets smerte - en erfaring som er av en slik karakter at den som rammes blir klar over situasjonens alvorlighetsgrad. I Marias tilfelle antyder legene at det er stor sannsynlighet for at hun ikke overlever. En slik situasjon er det som Marcel (1978) kaller en prøvelse. De berørte er fanget i en situasjon som medfører lidelse og i verste fall tilintetgjørelse. I Marcels tenkning er det nettopp slike grensesituasjoner som fremkaller det han kaller et genuint håp som ikke alltid kan forstås rasjonelt. Personen som befinner seg i en slik situasjon bruker ikke fornuften til å avveie oddsene men setter sin lit til at situasjonen kan få et positivt utfall. Ifølge Marcel gir denne troen kraft til å stå i det uutholdelige. Tomas sitt håp om et mirakuløst utfall av situasjonen er til stede, og det vokser for hver time Maria overvinner døden.

Marias alvorlige tilstand etter hjerneblødningen gjør at legene må forberede Tomas på at det er stor sannsynlighet for at han kommer til å miste henne. Det er viktig at de tegner et realistisk bilde av situasjonen som gir ham mulighet til å forberede seg selv og barna på det som kan skje. Den tyske filosofen Martin Heidegger (1927/2001) fastslår at mennesket er et meningssøkende vesen fra fødsel til død. Som mennesker prøver vi å fortolke vår tilværelse for å skape forståelse av det som foregår rundt oss. Også i Frankls (1993) skildringer er det tydelig at det er en sammenheng mellom håp og mening. Å lete etter mening i en situasjon som i utgangspunktet virker håpløs og meningsløs er en egenskap som er gitt oss i kraft av å være menneske. Informasjonen som Tomas får av legene og sykepleierne i akuttfasen gir mening. Dette støtter hans framtidshåp om at kona kan klare seg og gir ham styrke til å holde ut ved sykesengen.

Det at legene gir en realistisk og forståelig informasjon er alene ikke nok til at Tomas føler seg håpefull. Det som er viktig for ham på dette tidspunkt, er den omsorgsfulle og empatiske holdningen han møter hos leger og sykepleiere. Han føler seg trygg og inkludert, selv om han befinner seg i en høyteknologisk avdeling hvor hans kone er fullstendig avhengig av avanserte maskiner og kyndige hjelpere for å kunne opprettholde livsviktige funksjoner. Den omsorg personalet viser i stellesituasjoner og i kommunikasjon med hans kone, gjør at han kan føle seg trygg på at hun er i gode hender. Han føler seg inkludert som del av en stor familie i intensivavdelingen hvor alle har samme mål - å redde Maria. Å ha et felles mål gir ham styrke og livskraft slik at han makter å forholde seg til svingningene i hennes tilstand. Her er vi inne på det som Farran og kolleger (1995) omtaler som håpets hjerte, nemlig håpets relasjonelle komponent. Personalet på intensivavdelingen viser forståelse for familiens situasjon. De er til stede, og de vet hva Maria og Tomas har behov for. Tomas 
har tillit til dem og han tør å slappe av i trygg visshet om at Maria blir ivaretatt. Pleierne på intensivavdelingen er dyktige i sin jobb, og i tillegg yter de medmenneskelig omsorg. Noen ganger gjør sykepleierne mer for ham og kona enn det han forventer. Dette tydeliggjøres i eksemplet hvor sykepleieren nekter å gå av vakt før hun vet at Maria klarer å puste selv, etter at respiratoren er koblet fra. Hun setter Marias behov fremfor sine egne fordi hun vet hvor mye kontinuitet betyr i denne avgjørende sykdomsfasen.

Det eneste Maria selv husker fra denne tiden som strekker seg over cirka tre uker, er drømmer fra et grenseland mellom liv og død. Hun forteller:

«Det virket på meg som om min sфnn var i redningshelikopteret, og at han reddet meg ... døden skremte meg ikke fordi det var meningen at jeg skulle vare sammen med min lille familie ... min sønn hjalp meg hele tiden, han var min redningsmann ... men så fikk jeg for meg dette synet av en tynn høy mann med en lang svart frakk ... Han vinket meg til seg, men jeg ville ikke komme til ham, og han sa: 'Mange folk $i$ byen din kommer til å bli lei seg når du dør Maria.'

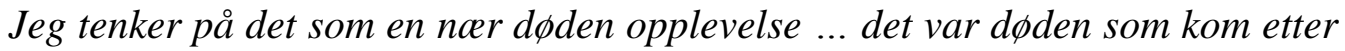
meg mens jeg var veldig syk ... det var skremmende ...»

Marias drømmer og nær døden opplevelser trer frem som livlige minner i hennes fortelling. Sønnen fremstår som hennes redningsmann, og hun er trygg på at hun vil overleve og bli gjenforent med sine kjære. Familien fremstår som livbøyen og blir en metafor på hennes håp om overlevelse (Kitzmüller, Asplund \& Häggström, 2012). På den andre siden vinker den svarte mannen til henne og vil ta henne med seg, men Maria nekter. Når hun våkner av sin komatøse tilstand er ektefellen det første hun ser, og det gir henne styrke til å fortsette kampen om å overleve for hun vil være sammen med sin lille familie. I løpet av intervjuet med Maria fremhever hun den betydningen som ektefellen har hatt for henne gjennom hele sykdomsforløpet:

"[På intensivavdelingen]: mange ganger sa jeg til mannen min: 'Ta meg med hjem, kan du ikke ta meg med hjem? Du kan bare legge meg på en båre bak $i$ bilen ...' Jeg skulle jo vare sammen med den lille familien min. [Under rehabiliteringsoppholdet]: Han kjфrte $100 \mathrm{~km}$ hver dag for å bes $\phi$ ke meg. [Etter hjemkomst]: Han gikk alltid sent på jobb fordi han hjalp meg opp og inn i dusjen og fikk på meg klarne. Han måtte gå ned $i$ stilling fordi han alltid kom for sent på arbeid. Jeg satt $i$ rullestol $i$ halvannet års tid ... men da var mannen min helt utrolig. Han dro meg ut på trening. Vi trente hver dag. Han skal ha all are. Jeg har hatt veldig god støtte av ham ... Vi bruker masse tid på å snakke sammen. Vi har et bra ekteskap, og vi klarer det godt.»

Omsider blir Marias tilstand mer stabil, og hun kommer til bevissthet og klarer å puste på egen hånd. Etterhvert blir hun overført til en vanlig sengepost. En av hennes første minner er når sykepleierne prøver å få henne ut av sengen. Maria 
blir klar over at kroppen hennes ikke lystrer. Hun føler seg fullstendig lammet, og hun har ikke kontroll over sine bevegelser. Deler av kroppen føles fremmed, som om de ikke tilhører henne:

«Jeg hadde ingen følelser $i$ min venstre arm, jeg så på den og tenkte at den var som en griselabb ... de tok meg ut av sengen og jeg sa: 'Herregud, jeg kan ikke holde meg oppreist, mine føtter barer meg ikke ...' Jeg kan ikke huske at noen fortalte meg hva som hadde skjedd.»

Den første tiden etter at Maria våkner er preget av motgang og sorg over det hun har tapt. Hun lengter etter å få svar på sine spørsmål og ser frem til å få snakke med psykolog:

«Jeg gledet meg til den første samtalen med psykologen. Ingen hadde snakket med meg om noen ting. Jeg hadde en lang liste på hva jeg skulle ta opp med psykologen ... og så skulle han bare teste meg. Jeg var så skuffet, jeg trodde jeg skulle få snakke med psykologen om alle spørsmålene, og han bare testet meg, og jeg gjorde det dårlig [på testene] ... Når det skjer en annen ulykke står et team klar for å hjelpe ... men dette er jo en stor ulykke det også ... og det er ingen som spфr deg om noen ting.»

Det dårlige resultat fra de kognitive testene forsterker Marias fortvilelse. Sykepleierne på sengeposten makter ikke å se personen som ligger hjelpeløs og fortvilt i sengen, og de klarer ikke å støtte hennes sorgarbeid. Mangel på omsorg og empati fører til at Marias skjøre selvfølelse brytes ned ytterligere. Marias håp får ingen næring. Enkelte minner fra sykehusoppholdet gjør henne trist fortsatt:

«Jeg følte at jeg måtte på do veldig ofte, og jeg tilkalte sykepleierne for å be om et bekken, men det kom bare en dråpe. De ble så irriterte over at jeg ringte på bjella når det ikke kom noe. Etter at jeg hadde fått klyster ringte jeg på og ba om å få komme på bekken ... men de sa: 'Har ikke du en plastbleie, da kan du bare gjøre i sengen.' Det sa de til meg flere ganger, det var så nedverdigende, jeg synes det var forferdelig ... og etterpå fikk de masse arbeid med å skifte på sengen ... de klaget også over at jeg var så tung å stelle ... jeg ble så sint når de sukket og stønnet over at jeg var så tung ... Når de serverte mat glemte de å rense vekk bein, og hvis det var egg glemte de at jeg bare hadde ei hånd ... Ofte når mannen min kom på bes $\phi k$ satt jeg med egg eller middag $i$ håret fordi ingen hadde hjulpet meg ... de tenkte at jeg skulle klare det selv.»

Maria savner innlevelse og forståelse fra pleiepersonalet på sengeposten og blir sittende igjen med en følelse av å være til bry. Hun opplever episoder hvor pleiepersonalet opptrer følelsesløst, likegyldig og lite profesjonelt når de steller henne, noe som truer hennes håp og livsmot. Hun utsettes for krenkelse og mister enda mer av kontrollen over sin egen kropp. Sykdommen har forandret Marias utseende og fratatt henne viktige funksjoner noe som har svekket hennes 
selvfølelse. Pleiernes uprofesjonelle holdninger og opptreden bryter ned Marias skjøre selvbilde og setter tydelige spor. De blir synlige når hennes fortellingen fortsatt blir ledsaget av gråt, noe som viser tydelig at helsepersonell bør være varsom og vise innlevelse i stellesituasjoner. Ifølge Farran og kolleger (1995) er det viktig at personen føler kontroll over sin situasjon for å kunne mobilisere håpets rasjonelle komponent. $\AA$ bli fratatt kontrollen over grunnleggende kroppslige funksjoner kan føles som å miste kontrollen over eget liv, noe som Farran og kolleger anser som spiren til håpløshet og resignasjon.

Etter at Tomas hadde opplevd god omsorg og støtte på intensivavdelingen, ikke minst gjennom den gode og varsomme nærhet som sykepleierne hadde vist hans kone i stellesituasjoner, blir han nå konfrontert med dystre framtidsutsikter når Maria våkner fra koma:

«Prognosen var: sengeliggende for resten av livet. Og jeg husker det som om det var i dag. Jeg spurte nevrokirurgen og sjefsfysioterapeuten: 'Men hvis vi trener med henne, så kan det jo ...?' 'Nei, sa nevrokirurgen, $i$ beste fall, jeg understreker $i$ beste fall kan hun bare vekten $i$ det hun forflyttes fra seng til rullestol.' ... Jeg så henne for meg da, det var ingen mulighet, og da husker jeg at jeg begynte å gråte. Det var veldig tøft og det ble formidlet på en dårlig måte. Det tok bort alle mine håp for fremtiden! Det var det eneste jeg bebreider dem for, at de stilte en prognose som var fullstendig feil.»

For Tomas er den overilte prognosen om Marias dystre framtidsutsikter vanskelig å bære fordi den fratar ham håpet for en felles fremtid sammen med henne. Han ser henne for seg sengeliggende og fullstendig pleietrengende. Sannsynligvis var legenes prognoser basert på en fornuftsmessig kalkulert antakelse i tråd med andre liknende tilfeller. Legenes prognoser tar ofte utgangpunkt $\mathrm{i}$ et naturvitenskapelig paradigme som bygger på statistisk evidens. I Marias tilfelle glemmer legene å ta høyde for hennes individuelle ressurser, hennes mestringspotensial og den støtten som finnes rundt henne i form av en ressurssterk og dedikert ektefelle. Marcel (1978) hevder at håp og kalkulerende fornuft er direkte motsetninger som ikke kan gå hånd i hånd. Ifølge Marcel kan vi ha et håp, selv om det ikke er noen fornuftsmessig grunn til det. Han hevder at håp ikke kan vurderes ut fra et objektivt ståsted fordi personens indre motivasjon ikke er synlig derfra. Så lenge personen selv mener at det er grunn til å håpe, vil vedkommende ha tro på livet. Denne troen kjennetegner håpets spirituelle side. Farran og kolleger (1995) beskriver troen som en overskridende og overvinnende kraft. Flere filosofer ser en sterk sammenheng mellom håp og tro (Marcel, 1978; Tillich, 1965). Denne troen kan være av religiøs eller spirituell natur men den kan også være knyttet til en sterk tro på egne ressurser eller tilliten til at de personer som har betydning i ens liv vil stille opp. 


\section{Håp og livsmot i rehabiliteringsfasen}

Etter at Maria blir overflyttet til lokalsykehuset klarer en dedikert fysioterapeut å tenne et nytt håp i Tomas og Maria. Han forsikrer paret at han ikke skal gi opp før han har fått Maria på beina igjen. Tomas viser stor glede når han forteller:

«Fysioterapeuten sa: 'Klart vi skal trene med henne, dette skal vi klare ... bare vent og se!' Og da skjønte jeg at kanskje gikk det an, kanskje kunne hun stå $i$ hvert fall, det hadde jo vart utrolig bra om hun kunne stå på egne ben ... vi ble møtt med - dette skal gå!»

I motsetning til legene som stiller Marias prognoser ut fra et naturvitenskapelig kunnskapsgrunnlag, tar fysioterapeuter i bruk flere kunnskapstradisjoner når de arbeider med henne. De tar utgangspunkt i hvem Maria er som person, og de forsøker å mobilisere hennes mestringsstrategier og læringspotensial. De har tro på hennes ressurser og gir henne mulighet til medvirkning. I tillegg «pusher» de henne mot et mål som ligger der i det fjerne - å kunne gjenvinne gangfunksjonen og klare seg selv i dagliglivet. Deres tålmodige og iherdige innsats gjør at ekteparet klarer å holde fast i håpet om en bedre fremtid. Etter kort tid med intensiv trening klarer Maria å stå på egne ben. Fysioterapeutene gjør fremgangen tydelig for henne, og hun tør å gi seg i kast med nye utfordringer. Maria er stolt når hun lykkes med aktiviteter som hun tror er umulig for henne. Å kunne nå små milepæler gir henne selvtillit og støtter hennes håp om fremgang:

«Jeg sa til fysioterapeuten at jeg hadde lyst til å svømme, og han svarte: 'Ja, selvsagt, du kan lare det på nytt.' ... men jeg hadde mine tvil på grunn av min epilepsi: 'Hva om jeg får et epileptisk anfall?' Han svarte: 'Men vi står jo rett ved bassengkanten, vi kan dra deg opp, kom igjen, prøv!' Så prøvde jeg og jeg kunne svømme. Jeg ringte min mann rett etterpå og ropte i telefonen: 'Jeg kan svømme!' Det er nesten utrolig når du lykkes med noe som du ikke trodde du kunne gjøre. Jeg var så lykkelig, det var en stor seier!»

Fysioterapeutene tar utgangspunkt $i$ en personsentrert tilnærming når de arbeider med Maria. De tar tak i hennes mestringsressurser, hennes pågangsmot og de små fremskritt hun viser. Deres tilnærming er fremtidsrettet. Ifølge Frankl (1993:72-73) er det svært viktig å støtte opp om fremtidshåpet når tilværelsen preges av lidelser og uforutsigbarhet. For å kunne beholde troen på at livet har mening til tross for motgang, må mennesket få et holdepunkt i fremtidige mål. Fysioterapeutene lytter til hva som er viktig for Maria å oppnå. De hjelper henne med å sette realistiske mål og jobber sammen med henne for å nå dem. Fysioterapeutene støtter opp om Marias selvtillit og tiltro til egen fremgang. De pusher henne til å våge stadig større utfordringer, og de gjør henne oppmerksom på det hun klarer. Ifølge tenkningen til Farran og kolleger (1995) har fysioterapeutenes innsats betydning både for håpets relasjonelle og rasjonelle 
aspekt hos Maria. Hun får avgjøre selv hvorvidt hun skal våge seg ut i svømmebassenget. Fysioterapeutenes oppgave er å garantere hennes trygghet. Fra før av har de gjort seg fortjent til hennes tillit, noe som gjør at hun tør å ta sjansen. Resultatet er en viktig måloppnåelse og følelsen av å mestre en ferdighet som hun trodde var tapt. Hun mobiliserer sine ressurser og lykkes, noe som fremmer hennes motivasjon og utløser en livgivende og fremtidsrettet drivkraft. Opplevelsen fremstår som en milepel i hennes fortelling om fremgang og styrke.

Sakte men sikkert gjør Maria flere og flere fremskritt og etter mange måneder på et nytt rehabiliteringssenter er hun klar til å reise hjem. I hele sykdoms- og rehabiliteringsfasen tilbakelegger Tomas mange kilometer hver dag for å besøke Maria. Han går ned i halv stilling for å være sammen med henne så mye som mulig, og han fortsetter med det etter at hun kommer hjem. Paret må forholde seg til mange nedturer i løpet av den første tiden hjemme. For Maria blir det tydelig at det er mye som hun ikke klarer uten hjelp. Tomas må være der for henne 24 timer i døgnet. Han innser at han må få døgnkontinuerlig hjelp til henne hvis han skal fortsette i jobben sin.

«Jeg måtte hjelpe henne med alt, for eksempel å gå på toalettet. Vi måtte bygge et toalett på verandaen fordi hun ikke kunne gå i trapper. Hun måtte sove på stua og hun kunne ikke gå ned på badet før vi fikk en trappeheis. Hun satt $i$ rullestol i ett år ... Det verste var å få en personlig assistent til henne. Kommunen nektet ... men hun kunne jo ikke vare alene mens jeg var på jobb. Hjemmesykepleien kunne ikke vare der hele tiden. Jeg klagde til fylkesmannen og fikk medhold. Fylkesmannen konkluderte med at kommunen hadde gjort en saksbehandlingsfeil. Hun måtte jo bare ha hjelp, det var innlysende for alle andre enn kommunen ... Jeg måtte sloss for hvert eneste vedtak. Det var tøft, det tøffeste av alt etterpå!»

Selv om Tomas møter store utfordringer og motgang i forbindelse med Marias sykdom og rehabilitering, fortsetter han å støtte henne der det er mulig. Marias fremgang og pågangsmot gir ham kraft til å stå i denne kampen.

\section{Tilbake til «normalen»}

Elleve år har gått siden Maria fikk hjerneblødning, og når jeg kommer for å intervjue henne ønsker hun velkommen med kaffe og kaker. Maria har gjenvunnet gangfunksjonen, og flere andre følgetilstander etter hjerneslaget har bedret seg. Hun klarer seg selv i det daglige, og hun fremstår som energisk og livsglad. Jeg kjenner at hennes gode humør smitter over på meg, selv om det er alvorlige ting vi prater om. I løpet av intervjuet slår det meg flere ganger hvor sterk Marias livsmot er. Hun forteller: «Jeg har penger ... og heldigvis har jeg et godt humфr [ler] og stor livsappetitt, jeg vil vare med på alt som skjer ... jeg vil ha med meg alt, jeg har jo så masse å ta igjen som jeg ikke har fått med meg de første årene [etter hjerneslaget].» 
Maria fortsetter sin fortelling med å forklare hvor viktig det er for henne å få aksept og anerkjennelse, selv om hun har forsonet seg med et liv med funksjonshemming:

«For meg er det viktigste av alt å vare normal ... Så jeg spør meg selv: 'Ser jeg ikke normal ut, går jeg ikke normalt?' Jeg har merket meg at folk snakker annerledes til meg eller at de snakker over hodet på meg. Jeg blir rasende og lei meg når de tror jeg er psykisk utviklingshemmet ... Jeg er livredd for å bli puttet $i$ den boksen ... En gang sa en fysioterapeut til meg: 'Maria du vet jo at du har en stor hjerneskade.' Jeg ble veldig sint på henne og jeg gikk hjem og spurte mannen min: 'Er det sant at jeg har en hjerneskade?' Jeg synes det er vondt å vite at jeg har fått en hjerneskade. Jeg vil vare normal! ... Men jeg er mye tфffere nå. Jeg gjфr ting som jeg ikke torde å gjфre før. Det er godt å vite at jeg kan mestre de tingene til tross for hjerneskaden min.»

Når jeg spør Maria hvilken betydning håpet har hatt for henne i den tunge tiden etter hjerneblødningen, svarer hun:

«Jeg hadde et veldig sterkt håp, jeg ga aldri opp, jeg så fremover. Jeg bestemte meg for å vise dem at jeg skulle klare det, og spesielt overfor henne [lege] som sa at du må ikke tro at du blir bra igjen. Jeg blir jo aldri den jeg var, men jeg skal $i$ hvert fall bli bedre, håpet er der! Hvis noen tar fra meg det håpet, kan jeg like gjerne legge meg ned for å d $\phi$. Jeg har hele tiden hatt et håp om å bli bedre, og nå har jeg et håp om at jeg skal bli en god bestemor for mine barnebarn ... jeg har alltid et håp, ja jeg skal klare det, noe skal jeg klare ...»

I denne fortellingen viser Maria at håpet har gitt henne tro på egen styrke. Tomas på sin side inspireres av Marias livsmot og kontinuerlige fremgang:

«Det var godt å se livsgnisten hennes, vi trente masse, daglig, i årevis. Det er jo helt vanvittig å se henne $i$ dag, man ville aldri trodd at det var mulig. Jeg hadde jo vart glad bare hun kunne stå og gå noen steg med utgangspunkt $i$ den prognosen hun fikk. Nå har hun gått fem kilometer ... det ble seire hele veien, og det var kjempeviktig.»

Legenes dystre prognoser har en utilsiktet virkning på Maria. Prognosen utløser en form for 'livstrass' hos Maria, en overbevisning om at hun skal klare å motbevise spådommen. Det vises tydelig i Marias utsagn om at hun skal vise dem at hun skal bli bedre. Denne trassige overbevisning utløser en sterk motivasjon til å stå på som aldri før. Det negative blir snudd til noe positivt når Maria mobiliserer en tro på at det spesialistene anser som umulig, likevel ligger i hennes makt. Kombinasjonen av hennes pågangsmot og støtten fra en dedikert ektefelle og andre profesjonelle hjelpere, gjør det umulige mulig.

Tillich (1965) sier at håp er en visjonær kraft som driver oss mot fremtiden. For å kunne bevare håpet må man ha evnen til å se fremover. Også i Marcels (1978) 
tenkning bærer håpet på en kraft som driver oss nærmere den fremtiden vi håper for. Når vi er håpefulle klarer vi å trenge gjennom tiden, derimot vil tiden stå stille hvis vi blir fanget $\mathrm{i}$ håpløshet. Tomas og Maria bruker håpets drivkraft til å planlegge sin felles fremtid, og de fors $\varnothing$ ker å gjøre det beste ut av situasjonen. I Marias fortelling om hva hennes håp har betydd for henne, ligger det et sterkt vitnesbyrd om håpets livsbærende kraft, noe som Marcel (1978) ser som en budbærer for besinnelse og forsoning. Maria har forsonet seg med at hjerneslaget har gitt henne varige funksjonshemminger og forandret hennes liv, men det hindrer henne ikke å se fremover og håpe på at hun fortsatt vil klare å oppnå de mål hun setter seg. Håpet om å kunne være en god bestemor for sine barnebarn gir henne styrke til å takle de begrensninger som sykdommen har påført henne og hjelper henne å rette blikket fremover. Marias utsagn er et eksempel på den spirituelle eller overskridende dimensjon som håpet har. Maria har gjort seg smertelige erfaringer som følge av sykdom og funksjonsbegrensninger. Disse erfaringene har ført til en modenhet og styrke som gjør at hun klarer å heve seg over det som begrenser livet hennes, og at hun kan fokusere på det som gir henne håp og livsmot. Som Frankl (1993:80) uttrykker det, klarer hun å bevare «mot til å lide». Hun viser en kraft som overskrider lidelsen (123), og hun henter mening i det hun fortsatt kan gjøre for dem som betyr noe for henne.

\section{Håp og livsmot trenger støtte for å være en bærende kraft gjennom sykdom og lidelse}

Fortellingen om Maria og Tomas viser den viktige oppgaven helsepersonell har med tanke på å støtte opp om pasienter og pårørendes håp. Mine erfaringer som sykepleier i ulike praksisfelt tilsier at mange helsearbeidere er redd for å støtte håpet hos pasienter og pårørende fordi de ofte oppfatter deres håp som urealistisk. Men hva er et urealistisk håp, og for hvem fremstår håpet som urealistisk? Burde vi ikke respektere pasientens håp nettopp fordi den er en livsbærende kraft som gir mot og styrke til å fortsette livet og gjøre det beste under de betingelsene som råder? Marcel (1978:64) hevder at håp ikke er et fenomen som vi kan forstå som observatør fra utsiden. Dette tilsier at vi som utenforstående ikke bør kategorisere pasienter og pårørendes håp som realistisk eller urealistisk. Det er personen det gjelder og de som står nærmest som har kunnskaper om hvilke indre og ytre ressurser som er tilgjengelige. Dette er en kunnskap som vi som helsearbeidere ikke har. Vi kan ha formeninger om hva som er sannsynlig ut fra statistikker eller ut fra erfaringsmessig kunnskap, men hva som er mulig for akkurat denne pasienten er det vanskelig å forutsi. Derfor kan velmente prognoser ofte slå feil og gjøre vondt verre. Tiden er også en viktig faktor som helsepersonell ofte glemmer å ta høyde for. Det er gjort få studier som følger slagpasienter over tid, og de som ser pasienten i akuttfasen møter som regel ikke pasienten igjen senere i forløpet. Derfor mangler vi både erfarings- 
messig og forskningsmessig grunnlag til å forutsi hva som vil skje med den aktuelle pasienten i fremtiden.

Som forsker har jeg erfart at de som rammes av et alvorlig hjerneslag og deres ektefeller på et eller annet tidspunkt innser at det de opprinnelig hadde håpet på, ikke er mulig (Kitzmüller, Häggström, Asplund \& Gilje, 2012). Likevel var deres håp en kilde til livsmot, og tiden ble fylt med å finne viktige milepæler som det fortsatt var mulig å oppnå. Tillich (1965) sier at å håpe innebærer at man gir seg til å vente, men det er ikke en passiv og tilbakeholden venting, men en åpen mottakelighet for endring og utvikling. Han hevder at denne tålmodige og håpefulle ventetiden kan gjøre noe med individets indre utvikling og kan frembringe noe nytt som ikke kan oppnås med viljestyrke alene. En liknende refleksjon har vi allerede sett hos Marcel (1978:53) som understreker håpets 'tålmodige' karakter. Det ligger et viktig budskap i det Marcel og Tillich antyder. Å håpe er å gå inn i en tålmodig venteprosess. Som helsearbeidere har vi ikke rett til å gripe inn i denne viktige ventetiden for å påskynde den, men vi bør være tålmodige medspillere som i kraft av vår profesjonalitet vet hvordan vi skal gå frem for å støtte opp om håpet. Det er nettopp denne tålmodigheten som ofte settes på prøve i dagens høyeffektive helsevesen hvor det forventes raske resultater. $\AA$ støtte den som håper er en langsom prosess hvor pasient og pårørende må få rom til å gå veien i sitt eget tempo.

Informasjon har fått en viktig og velfortjent plass i dagens helsevesen og er en lovfestet rettighet som pasient og pårørende har (Pasient- og brukerrettighetsloven, 1999). Informasjonen skal sørge for at de får et godt grunnlag til å mestre utfordringene som sykdommen medfører. Likevel kan mye gå galt her. Hvis informasjonen ikke er tilpasset pasientens behov og ressurser, kan den lett gjøre vondt verre, og i verste fall kan den frata pasienten alt håp om en bedre livssituasjon. En av mine deltakere hadde på et tidlig tidspunkt i rehabiliteringsprosessen fått beskjed av legene at han kom til å bli rullestolbruker. Han mistet all motivasjon for å trene, for hva var vitsen hvis rullestoltilværelsen var uunngåelig? Unødvendig informasjon som skremmer pasientene eller tar motivasjonen fra dem gjør stor skade. Pasientens livsmot kan drukne i angsten for alt som muligens kan skje. Ifølge Tranøy (1986:169-170) har ikke all kunnskap en positiv velferdsverdi for mottakeren, selv om den kan ha en sannhetsverdi. Kunnskapen som legene her ønsker å formidle har sannhetsverdi utfra statistisk evidens, men den bidrar ikke til pasientens velferd fordi den kan motvirke håpet om fremgang og motivasjonen for å gjøre en innsats. Informasjon som berører pasientens framtidsutsikter bør gis med varsomhet og tilpasses sykdomsforløpet. Alt trenger ikke å bli fortalt med en gang, særlig ikke når mye fortsatt er usikkert. Ensidig negativ informasjon kan ha langsiktige konsekvenser og kan i verste fall kvele livsmotet. For en lege skal det både erfaring og mot til å innrømme at han eller hun ikke vet hvordan 
tilstanden vil utvikle seg. Det som i en slik situasjon kan være avgjørende er at legen holder muligheten åpen for at pasienten kan påvirke noe av sin situasjon selv. Informasjonen bør alltid ta høyde for det som står i pasientens makt. Som Maria uttrykker det: «Jeg har alltid et håp ... noe skal jeg klare».

I min praksis har jeg opplevd flere tilsynelatende mirakuløse tilfeller. Jeg har lært at det er mye vi ikke vet, selv om den medisinske kunnskapsutviklingen har nådd langt. Derfor bør vi være forsiktige med å si for mye eller være for skråsikre når vi informerer om pasientens fremtidige muligheter. Jeg har merket meg at et fellestrekk ved slike hendelser hvor det skjer en bedring eller helbredelse mot alle odds, er at det er sterke relasjoner mellom pasient og pårørende eller mellom pasient og helsearbeidere. I slike relasjoner er kjærlighet, medmenneskelighet og innlevelse en sterk drivkraft som gir håp om og tro på at situasjonen vil snu til det bedre. I den aktuelle fortellingen ser vi drivkraften i relasjonen mellom Maria og Tomas. Vi kan også se det i relasjonen mellom Tomas og de dedikerte sykepleierne på intensivavdelingen og mellom Maria og fysioterapeutene på rehabiliteringsavdelingen. Det de profesjonelle viser her, er både faglig dyktighet men også et sterkt medmenneskelig engasjement. Dette blir synlig i de gode og varsomme stellesituasjoner på intensivavdelingen og i fysioterapeutenes motiverende og støttende holdning senere i forløpet. Hvis vi skal se nærmere på hva som er viktige bærende elementer i relasjonen mellom ekteparet og de profesjonelle hjelperne, kan vi gå til psykiateren og filosofen Martin Buber (1998:75). Han hevder at bare gjennom en «ekte dialog» kan vi gjøre den andre gjeldende som et unikt menneske. Skal vi fremme den andres utvikling må vi anerkjenne ham og bekrefte ham (59). Buber ser bekreftelse som en viktig del av den terapeutiske relasjonen mellom pasient og profesjonell hjelper. For Buber er «inklusjon» en forutsetning for den «helbredende» relasjon (Scott, Scott, Miller, Stange, \& Crabtree, 2009). Maria blir inkludert av fysioterapeutene som ser hennes behov og lar henne ta egne avgjørelser. Samtidig blir hun sett som den sårbare personen hun er etter hjerneslaget, og hun får bekreftelse og motivasjon for å komme videre. Sykepleierne på intensivavdelingen makter å se Tomas som ektefellen som er i fare for å miste det kjæreste han har. Hos dem får han all den omtanke, trygghet og omsorg han trenger i den kritiske situasjonen han er i.

Håpets relasjonelle komponent er sannsynligvis en av de viktigste forutsetninger for at håpet kan bevares over tid. Maria og Tomas sin fortelling om tap og motgang, blir til en fortelling om tapperhet og fremgang, takket være Marias urokkelige livsmot og det sterke håpet ekteparet bærer på. Det som utvilsomt har påvirket utfallet er styrken i parets relasjon og de gode støttespillerne som hjalp dem videre på veien. Som profesjonelle helsearbeidere er vi privilegerte fordi vi kan hjelpe pasienter og pårørende med å holde fast i håpets livstråd. Vi kan gjøre dette ved å tre inn i en terapeutisk relasjon slik Buber (1998) beskriver den. En 
slik relasjon forutsetter en omsorgsfull tilnærming som kan aktivere helbredende krefter hos pasientene og støtte livsmotet til deres pårørende.

\section{Litteratur}

Brannigan, C., Galvin, R., Walsh, M. E., Loughnane, C., Morrissey, E.-J., Macey, C., . . Horgan, N. F. (2017). Barriers and facilitators associated with return to work after stroke: a qualitative meta-synthesis. Disability \& Rehabilitation, 39(3), 211-222. http://dx.doi.org/10.3109/09638288.2016.1141242

Buber, M. (1998). The knowledge of man: selected essays, edited with an introduction of Maurice Friedman. Amherst, N.Y.: Humanity Books.

Duncan, F., Wu, S., Mead, G. E., Duncan, F., Wu, S., \& Mead, G. E. (2012). Frequency and natural history of fatigue after stroke: a systematic review of longitudinal studies. Journal of Psychosomatic Research, 73(1), 1827.http://dx.doi.org/10.1016/j.jpsychores.2012.04.001

Edgley, S. R., \& Gershkoff, A. M. (2010). Common pain syndromes in stroke patients: review of two cases. Topics in Stroke Rehabilitation, 17(3), 179-182. http://dx.doi.org/10.1310/tsr-1703-179

Farran, C. J., Herth, K. A., \& Popovich, J. M. (1995). Hope and hopelessness: critical clinical constructs. Thousand Oaks, CA: Sage Publications. https://doi.org/10.1016/S1071-5754(96)90032-7

Frank, A. W. (2013). The wounded storyteller: body, illness, and ethics (2nd ed.). Chicago: University of Chicago Press.

Frankl, V. E. (1993). Kjempende livstro. Oslo:Aventura Forlag.

Heidegger, M. (1927/2001). Sein und Zeit. Tübingen: Max Niemeyer Verlag $\mathrm{GmbH}$.

Kitzmüller, G. (2012). Long-term experiences of living with stroke in a family context. Doctoral thesis, University of Tromsø, Troms $\emptyset$. (ISBN: 978-827589-369-5)

Kitzmüller, G., \& Asplund, K. (2018). Når livet blir snudd opp ned - familielivet etter hjerneslag sett i langsiktig perspektiv. Nordisk Sygeplejeforskning, 2018(1), 6-2. https://doi.org/10.18261/issn.1892-2686-2018-01-02

Kitzmüller, G., Asplund, K., \& Häggström, T. (2012). The long-term experience of family life after stroke. Journal of Neuroscience Nursing, 44(1), E113. https://doi.org/10.1097/jnn.0b013e31823ae4a1

Kitzmüller, G., Häggström, T., \& Asplund, K. (2013). Living an unfamiliar body: the significance of the long-term influence of bodily changes on the perception of self after stroke. Medicine, Health Care \& Philosophy, 16(1), 19-29. https://doi.org/10.1007/s11019-012-9403-y

Kitzmüller, G., Häggström, T., Asplund, K., \& Gilje, F. L. (2012). The existential meaning of couples' long-term experiences of living with stroke. Illness, Crisis \& Loss, 20(4), 339-362.

Marcel, G. (1978). Homo viator. Introduction to a Metaphysic of Hope (translated by Emma Craufurd). Illinois, Chicago: Gateway Editions Ltd. 
Pasient- og brukerrettighetsloven. (1999). Lov om pasient-og brukerrettigheter. (LOV-1999-07-02-63). Hentet 14.mars 2018 fra https://lovdata.no/dokument/NL/lov/1999-07-02-63

[Sist endret 01.07.2019. (LOV-2019-06-21-43)]

Salter, K., Hellings, C., Foley, N., \& Teasell, R. (2008). The experience of living with stroke: a qualitative meta-synthesis. Journal of Rehabilitation Medicine (Stiftelsen Rehabiliteringsinformation), 40(8), 595-602. https://doi.org/10.2340/16501977-0238

Schöttke, H., Giabbiconi, C.-M., \& Schöttke, H. (2015). Post-stroke depression and post-stroke anxiety: prevalence and predictors. International Psychogeriatrics, 27(11), 1805-1812. https://doi.org/10.1017/S1041610215000988

Scott, J. G., Scott, R. G., Miller, W. L., Stange, K. C., \& Crabtree, B. F. (2009). Healing relationships and the existential philosophy of Martin Buber. Philosophy, Ethics, and Humanities in Medicine : PEHM, 4, 11-11. doi:10.1186/1747-5341-4-11

Teasdale, T. W., \& Engberg, A. W. (2005). Psychosocial consequences of stroke: a long-term population-based follow-up. Brain Injury, 19(12), 1049-1058. https://doi.org/10.1080/02699050500110421

Tillich, P. (1965). The right to hope. Text: Romans 4, 18: »In hope he believed against hope«. Neue Zeitschrift für Systematische Theologie und Religionsphilosophie, 7(3), 371-377. https://doi.org/10.1515/nzst.1965.7.3.371

Tranøy, K.E. (1986). Vitenskapen, - samfunnsmakt og livsform. Oslo: Universitetsforlaget. https://www.nb.no/items/URN:NBN:no-nb_digibok_2007080901007 